\title{
Stability, adaptability and shelf life of Cantaloupe melon hybrids
}

\author{
Lenilton Alex de Araújo Oliveira ${ }^{1}$, Eudes de Almeida Cardoso², Anânkia de Oliveira Ricarte ${ }^{3}$, \\ Adriano Ferreira Martins ${ }^{4}$, José Maria da Costa ${ }^{5}$, Glauber Henrique de Sousa Nunes ${ }^{6}$ \\ Abstract - The adoption of melon hybrids by the productive sector necessitates a prior evaluation of the \\ productivity, quality and shelf life of their fruits. Due to the different environmental conditions under \\ which the hybrids are evaluated, an accentuated genotype-environmental interaction is expected to \\ become apparent and likewise play important role in manifestation of phenotypic traits. The objective \\ of the present work was to evaluate melon hybrids in the state of Rio Grande do Norte. The adaptability \\ and stability of the genetic values were estimated by the HMRPGV method (Harmonic Mean of the \\ Relative Performance of Genetic Values) for the following traits: yield, and soluble solids (SS) content \\ in the period between 2010 to 2015. In 2017, the more promising melon hybrids from previous trials \\ were evaluated under commercial conditions to determine the fruit's yield, quality and shelf life. \\ The predominance of the complex part of the genotype-environmental interaction was verified for \\ both yield and SS content. Hybrids HC-02 and HC-11 show promising traits when grown under the \\ conditions of the Mossoró-Assu Agricultural Complex owing their high stability, adaptability, yield, \\ and fruit quality. Hybrids HC-02, HC-11, and 'Hy Mark' are suitable as international exports due to \\ their long shelf life. \\ Index terms: Cucumis melo, BLUP (Restricted Maximum Likelihood / Best Linear Unbiased \\ Prediction), mixed models, fruit exportation, fruit quality.

\section{Estabilidade, adaptabilidade e vida útil pós-colheita de híbridos de melão Cantaloupe}

Corresponding author: anankiaricarte@gmail.com

Received: January 09, 2019 Accepted: July 24, 2019

Copyright: All the contents of this journal, except where otherwise noted, is licensed under a Creative Commons Attribution License.

(cc) $\mathbf{E Y}$
Resumo - A adoção de híbridos de melão pelo setor produtivo requer uma prévia avaliação quanto à produtividade, qualidade e vida útil pós-colheita de seus frutos. Devido as diferentes condições ambientais em que os híbridos são avaliados, espera-se que ocorra acentuada interação genótipos $\mathrm{x}$ ambientes e que a mesma tenha um importante papel na manifestação fenotípica. Diante disso, o presente trabalho teve como objetivo avaliar híbridos de melão no Estado do Rio Grande do Norte. Estimou-se a adaptabilidade e estabilidade dos valores genotípicos preditos pelo método MHPRVG (Média Harmônica da Performance Relativa dos Valores Genéticos) para os caracteres: produtividade e teor de sólidos solúveis (SS) no período de 2010 a 2015. Em 2017, avaliou-se os híbridos mais promissores em condições de cultivo comercial para produtividade, qualidade e vida útil pós-colheita. Verificou-se interação genótipos x ambientes para produtividade e SS com predomínio da parte complexa da interação. Os híbridos HC-02 e HC-11 são promissores para cultivo nas condições de semiárido do Agropolo Mossoró-Assu por possuir elevadas estabilidade, adpatabiliadade, produtividade e qualidade dos frutos. Os híbridos HC-02, HC-11 e 'Hy Mark' possuem vida útil pós-colheita que permitem sua comercialização no mercado externo.

Termos para indexação: Cucumis melo, BLUP (Restricted Maximum Likelihood / Best Linear Unbiased Prediction), modelos mistos, exportação de frutos, qualidade de fruto.

\footnotetext{
${ }^{1}$ Engenheiro Agrônomo, Dr. Professor EBTT no Instituto Federal de Educação, Ciência e Tecnologia do Pará (IFPA), Breves-PA, Brasil. E-mail: lenilton@ufersa.edu.br ${ }^{(O R C I D}$ 0000-0002-1072-7997)

${ }^{2}$ Engenheiro Agrônomo, Dr. Professor titular na Universidade Federal Rural do Semi-Árido (UFERSA), Mossoró-RN, Brasil. E-mail:eudes@ ufersa.edu.br (ORCID 0000-0003-4114-9197)

${ }^{3}$ Engenheira Agrônoma, Doutora em Fitotecnia pela Universidade Federal Rural do Semi-Árido, Mossoró-RN, Brasil. E-mail: anankiaricarte@ gmail.com (ORCID 0000-0002-9676-8967)

${ }^{4}$ Engenheiro Agrônomo, Mestrando em Fitotecnia na Universidade Federal Rural do Semi-Árido, Mossoró-RN, Brasil. E-mail: adrianomartinsfe@ gmail.com(ORCID 0000-0002-0481-4066)

${ }^{5}$ Engenheiro Agrônomo, Doutor em Fitotecnia pela Universidade Federal Rural do Semi-Árido, Mossoró-RN, Brasil. E-mail: jmc.atm@hotmail.

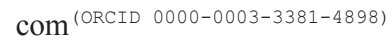

${ }^{6}$ Engenheiro Agrônomo, Dr. Professor adjunto na Universidade Federal Rural do Semi-Árido, Mossoró-RN, Brasil. E-mail: glauber@ufersa. edu.br ${ }^{\text {(ORCID } 0000-0002-7189-2283)}$
} 


\section{Introduction}

Melons (Cucumis melo L) are among the most farmed cucurbits in the world. In Brazil, the Northeastern States of Rio Grande do Norte and Ceará are responsible for most of the production and export of the fruit. This achievement owes to climatic conditions of the region, that favor fruit development. For instance, the high temperatures $\left(>28^{\circ} \mathrm{C}\right)$, low rainfall $\left(\approx 600 \mathrm{~mm} \mathrm{ano}^{-1}\right)$, and high sunlight exposure. The utilization of new technology by farmers is yet another contributing factor that has led to the success of this crops. The European Community is the principal market for the melons grown in the Brazilian Semi-arid region.

Yellow melons are the most widely grown variety in Brazil, belonging to the inodorus Group known as inodorus Naud. In order to offer more options to consumers, many companies nevertheless grow other varieties, among which figures the Cantaloupe melon. This melon belongs to the cantalupensis Group Naud, and its main characteristics are the densely netted exocarp, distinct color, and most notably its aroma. Cantaloupes account for approximately $16.09 \%$ of melons exported from the Port of Natal (SALES JÚNIOR et al., 2006). This percentage currently persists, with farmers tending towards harvesting increasingly larger crops of Cantaloupes in order to take advantage of the the higher trade prices in the international markets.

Seed companies have continuously developed various Cantaloupe cultivars to supply farms so that the demands of these growing markets can be met. However, the adoption of any of these hybrids requires a prior evaluation of fruit yield and quality in order to ensure greater safety in the recommendation of hybrids for the various cultivation conditions (NUNES et al., 2005). Moreover, due to the different environmental conditions under which the hybrids are evaluated, an accentuated genotype-environmental interaction is expected to become apparent and likewise play an important role in the manifestation of phenotypic. This event has occurred in many trials aimed at the evaluation of melon cultivars in the Mossoró-Assu Agricultural Complex (ARAGÃO et al., 2015; FREITAS et al., 2007; GUIMARÃES et al., 2016; NUNES et al., 2006). Once the presence of the interaction is detected, measures must be promptly taken so as to mitigate this effect. One of the most used methods is the use of genotypes with high stability and adaptability.

Studies on genotypes and their interactions with different environments are key as they make possible the identification of cultivars with high adaptability and stability, thus aiding researchers in recomending the most appropriate genotypes for a given region (YAN et al., 2011).

Traditionally, the methods used to study adaptability and stability consider the effects of genotypes as fixed. However, in recent years, the number of studies that consider the effect of genotypes as random has increased. Assuming the effects of genotypes as random allows for the obtainment of best linear unbiased predictions (BLUP) of the effects of genotypes and $\mathrm{G} \times \mathrm{E}(\mathrm{RESENDE}$, 2007). This concept has been used in conjunction with the Maximum Restricted Likelihood (REML) method as the ideal procedure for estimating variance components, maximizing the likelihood function of the residues (PATTERSON; THOMPSON, 1971).

In this context, Resende (2002) proposed the method titled "Harmonic Mean of the Relative Performance of Genotypic Values (HMRPGV) to select genotypes in a single measure on the scale of the evaluated trait, simultaneously taking into account the factors of productivity, adaptability and stability from the BLUP predictors. This method has been applied to both perennial crops (PUPIN et al., 2015), and annual crops such as beans (CARBONELL et al., 2007), carrot (SILVA et al., 2011), rice (REGITANO NETO, 2013), and cowpeas (TORRES et al., 2015). However, there are no reported uses of this method with melon crops.

The aim of this work was to evaluate the performance of Cantaloupe melon hybrids in the MossoróAssu Agricultural Complex, in the state of Rio Grande do Norte, Brazil.

\section{Materials and Methods}

A total of 13 experimental hybrids were evaluated and divided into three groups. The 'Hy Mark' hybrid was used as the control group because it is widely cultivated in the Mossoró-Assu Agricultural Complex (Table 1). All hybrids, including the control variety, belong to the Cantaloupe group, having the basic characteristics as the intense netting on the exocarp, the salmon coloration of the mesocarp, the distinct aroma and monoicous sexual expression.

The trials were carried out at municipalitites of Mossoró ( $5^{\circ} 11^{\prime} \mathrm{S}, 37^{\circ} 21^{\prime} \mathrm{W}$, altitude: 18$)$, Baraúna (5 $05^{\prime} \mathrm{S}, 37^{\circ} 38^{\prime} \mathrm{W}$, altitude: 94$)$, Assu ( $5^{\circ} 34^{\prime} \mathrm{S}, 36^{\circ} 54^{\prime}$ W altitude: 27), and Ipanguassu ( $5^{\circ} 05^{\prime} \mathrm{S}, 37^{\circ} 38^{\prime} \mathrm{W}$, altitude: 94), all of which are located in the MossoróAssu Agricultural Complex, in differing years of sowing. Fertilization and irrigation observed the recommendation of the initial analyzes of the soil. All usual melon farming practices such as pest and disease control, and weed removal (NUNES et al., 2011b), were applied in compliance with those traditionaly adopted in the state of Rio Grande do Norte.

The trials were carried out in completely randomized block designs with three replications. Each plot was 6 meters long, seperated by 2 meters apart. The plants were spaced 0.3 meters apart, with one cultivated plant per pit. Each plot had 20 plants with those at the end 
forming the border. The remaining sixteen plants in the center were used for the studies.

The main traits evaluated were yield and SS content. Both traits have been pointed out by growers of the Mossoró-Assu Agro-industrial Complex as the most important ones. The yield was obtained through the sum of the weight of all fruits harvested per plot. The fruits were individually weighted on an electronic scale (from 0 to $25 \mathrm{~kg}$ ). The results were expressed in $\mathrm{tha}^{-1}$. The total SS content was determined by refractometer using filtered juice from melon flesh blended in a kitchen blender. The reading was taken on a digital refractometer with automatic temperature correction (scale from 0 to $32 \%$ ). After the hybrids were evaluated, those of greater prominence were cultivated in observance of the farmer's growing conditions. The fruits were then evaluated on their yield, number of fruits per plant, average fruit weight, pulp thickness and firmness, and SS. In order to estimate the shelf life of fruits kept in cold storage $\left(4.0^{\circ} \mathrm{C}\right)$, the internal and external appearances were evaluated daily up to 30 days after harvest as discribed by Gomes (2001).

A statistical analysis was performed according to statistical model 54 of the SELEGEN-REML / BLUP software (REZENDE, 2007). This model corresponds to $\mathrm{ay}=\mathrm{Xb}+\mathrm{Zg}+\mathrm{Wc}+\mathrm{e}$, where $\mathrm{y}, \mathrm{b}, \mathrm{g}, \mathrm{c}$, and correspond, respectively, to the data vectors, fixed effects (block means across environments), genotype effects (random), genotype $\mathrm{x}$ environment (random) interaction effects, and random errors. While $\mathrm{X}, \mathrm{Z}$ and $\mathrm{W}$ are the incidence matrices for $\mathrm{b}, \mathrm{e}$, and $\mathrm{c}$, respectively.

The assumed distributions and mean structures (S) and variances (Var) were the following:

$$
\mathrm{S}\left[\begin{array}{l}
\mathrm{y} \\
\mathrm{g} \\
\mathrm{c} \\
\mathrm{e}
\end{array}\right]=\left[\begin{array}{c}
\mathrm{Xb} \\
0 \\
0 \\
0
\end{array}\right] ; \operatorname{Var}\left[\begin{array}{l}
\mathrm{y} \\
\mathrm{c} \\
\mathrm{p}
\end{array}\right]=\left[\begin{array}{ccc}
\mathrm{I} \sigma_{\mathrm{g}}^{2} & 0 & 0 \\
0 & \mathrm{I} \mathrm{v}_{\mathrm{c}}^{2} & 0 \\
0 & 0 & \mathrm{I} \sigma_{\mathrm{e}}^{2}
\end{array}\right] \text {, while }
$$

the adjustment of the model was realized through the following mixed model equations:

$$
\begin{gathered}
{\left[\begin{array}{ccc}
\mathrm{X}^{\prime} \mathrm{X} & \mathrm{X}^{\prime} \mathrm{Z} & \mathrm{X}^{\prime} \mathrm{W} \\
\mathrm{Z}^{\prime} \mathrm{X} & Z^{\prime} \mathrm{Z}^{+}+\lambda_{1} & \mathrm{Z}^{\prime} \mathrm{W} \\
\mathrm{W}^{\prime} \mathrm{X} & \mathrm{W}^{\prime} \mathrm{Z} & \mathrm{W}^{\prime} \mathrm{W}+\mathrm{I} \lambda_{2}
\end{array}\right] \times\left[\begin{array}{l}
\hat{\mathrm{b}} \\
\hat{\mathrm{g}} \\
\hat{\mathrm{c}}
\end{array}\right]-\left[\begin{array}{c}
\mathrm{X}^{\prime} \mathrm{y} \\
Z^{\prime} \mathrm{y} \\
\mathrm{W}^{\prime} \mathrm{y}
\end{array}\right]} \\
\text { Where } \lambda_{1}=\frac{\sigma_{\mathrm{e}}}{\sigma_{\mathrm{g}}^{2}}=\frac{1-\mathrm{h}_{\mathrm{g}}^{2}-\mathrm{c}^{2}}{\mathrm{~h}_{\mathrm{g}}^{2}} \quad \mathrm{~h}_{\mathrm{g}}^{2}=\frac{\sigma_{\mathrm{g}}^{2}}{\sigma_{\mathrm{g}}^{2}+\sigma_{\mathrm{c}}^{2}+\sigma_{\mathrm{g}}^{2}}
\end{gathered}
$$

corresponds to individual heritability in a broad sense in the block; $\mathrm{c}^{2}=\frac{\sigma_{\mathrm{c}}^{2}}{\sigma_{\mathrm{g}}^{2}\left|\sigma_{\mathrm{c}}^{2}\right| \sigma_{\mathrm{g}}^{2}}$ corresponds to the determination coefficient of the genotype $\mathrm{x}$ environment interaction effects; $\sigma^{2}$ is the genotypic variance between hybrids (genotypes) of melons; $\sigma_{c}^{2}$ is the variance of the genotype-environmental interaction; $\sigma_{\mathrm{e}}^{2}$ is the residual variance between plots; $\mathrm{r}_{\mathrm{gloc}}=\frac{\sigma_{\mathrm{c}}^{2}}{\sigma_{\mathrm{g}}^{2} / \sigma_{\mathrm{c}}^{2}}=\frac{\mathrm{h}_{\mathrm{s}}^{2}}{\mathrm{~h}_{\mathrm{g}}^{2} \mid \mathrm{c}^{2}}$ corresponds

to the genotypic correlation of genotypes across different environments.

The iterative estimators of the variance components, by REML, via ME algorithm, are:

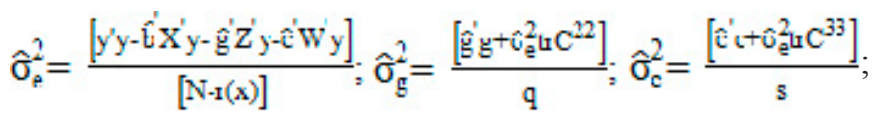

where $\mathrm{C}^{22}$ and $\mathrm{C}^{33}$ stem from

$\mathrm{C}^{-1}=\left[\begin{array}{lll}\mathrm{C}_{11} & \mathrm{C}_{21} & \mathrm{C}_{13} \\ \mathrm{C}_{21} & \mathrm{C}_{22} & \mathrm{C}_{23} \\ \mathrm{C}_{31} & \mathrm{C}_{32} & \mathrm{C}_{33}\end{array}\right]^{1}=\left[\begin{array}{lll}\mathrm{C}^{11} & \mathrm{C}^{12} & \mathrm{C}^{13} \\ \mathrm{C}^{21} & \mathrm{C}^{22} & \mathrm{C}^{23} \\ \mathrm{C}^{31} & \mathrm{C}^{32} & \mathrm{C}^{33}\end{array}\right] \quad$, wherw $\mathrm{C}$

is the coefficient matrix of the mixed model equations; $t r$ the matrix trace operator; $\mathrm{r}(\mathrm{x})$ the rank of the matrix $\mathrm{X}$; $\mathrm{N}, \mathrm{q}$ and $\mathrm{s}$, are the total number of data, the number of genotypes, and the number of genotype $\mathrm{x}$ environment combinations, respectively.

The empirical BLUP predictors of the free genotypic values of the interaction were obtained by $\hat{\mu}^{+}$ $\hat{\mathrm{g}}_{\mathrm{i}}$, where $\hat{\mu}$ is the mean of all the environments and $\hat{g}_{\mathrm{i}}$ is the free genotypic effect of the genotype-environmental interaction. For each environment $j$, the genotypic values were predicted by $\hat{\mu}+\hat{g}_{i}+\hat{g e}_{i j}$, where $\hat{\mu}_{j}$ is the mean of the environment $j, \hat{g}_{i}$ is the genotype effect and $\hat{e}_{\mathrm{ij}}$ is the effect of the genotype-environmental interaction concering genotype i.

The joint selection, taking into account the trait in question simultaneously to the stability and adaptability of the melon genotypes (hybrids) is given by the statistics harmonic mean of the relative performance of predicted genotypic values HMRPG $V_{i}-\frac{n}{\sum_{j=1}^{n} \frac{l}{V_{v_{1 j}}}}$, where $n$ is the number of locals where the genotype $\mathrm{i}$ was evaluated, $\mathrm{Vg}_{\mathrm{ij}}$ is the genotypic value of the genotype $i$ in environment $j$, expressed as proportion of the mean of that environment.

\section{Results and Discussion}

In the later stages of breeding programs, it is paramount that a high degree of precision be used when selecting cultivars in order to accomplish the aim of the program, due to the small differences among genotypes. Selection accuracy may be considered in order to verify the quality of a trial. Such a parameter takes into account the experimental coefficient of variation the number of replications, and the genotypic coefficient of variation simultaneously (REZENDE e DUARTE, 2007). According to the accuracy (Ac) classification proposed by Rezende and Duarte (2007), the accuracy of the productivity of the first group was low $\left(0,10 \leq A c_{g} \leq 0,40\right)$; the second group's was high $\left(0,70 \leq A c_{g} \leq 0,85\right)$, and the third group of hybrids was very high $\left(0,90 \leq \mathrm{Ac}_{\mathrm{g}} \leq 0,99\right)$. In regards to 
SS, moderate accuracy was observed $\left(0,50 \leq \mathrm{Ac}_{\mathrm{g}} \leq 0,65\right)$ on the groups 1 and 3, and very high accuracy on trial 2 (Table 2). High accuracy is indicative of greater efficiency of the inference on the genotypic value of the cultivar, that is, accuracy refers to the correlation between the predicted and the true genotypic values. These results are the first to report estimates of accuracy with regards to Cantaloupes. This information is useful for future trials whit melon crops in the Mossoró-Assu Agricultural Complex.

A significant effect for productivity was observed in each group of hybrids by the chi-square test ( $p<$ $0,05)$, thus indicating heterogeneity among the analyzed genotypes. In evaluations of Yellow melon (GURGEL et al., 2005; NUNES et al., 2006), Galia melon (NUNES et al., 2011b) and Cantaloupe melon cultivars (NUNES et al., 2011a) carried out in the Mossoró-Assu Agricultural Complex, differences of productivity were observed among the genotypes. Conversely, the verified results of SS content observed were only significant in the second group of hybrids.

The heritability of the genotype mean is estimated when the averages of the blocks are used as the selection criterion (RESENDE, 2002). The observed values for productivity of hybrids groups 1, 2 and 3 were $10 \%$, $60 \%$ and $80 \%$, respectively (Table 2). For SS content, the estimates for groups 1,2 and 3 were $30 \%, 80 \%$ and $30 \%$, respectively. Heritability is a ratio between genetic phenotypic variance. The higher the heritability estimate, the greater the reliability in the selection of hybrids based on predicted genotypic values. In this case, the best options for selection were verified in groups 1 and 2 for productivity, and in group 2, for SS content, with estimates $\geq 60 \%$. Estimates of heritability for productivity and SS content are within the ranges observed in some melon crops in the Mossoró-Assu Agricultural Complex (MELO et al., 2011; SILVA et al., 2011; ARAGÃO et al., 2015, GUIMARÃES et al., 2016).

The genotype-environmental interaction was verified for the two variables in the evaluated groups (Table 2). The interaction shows the different behavior of the hybrids in different environments. The genotypeenvironment interaction in melon crops has been verified in the evaluation studies of melon hybrids (FREITAS et al., 2007, NUNES et al., 2005, NUNES et al., 2006, NUNES et al., 2011a,b), as well as in the evaluation of families (ARAGÃO et al., 2015, GUIMARÃES et al., 2016; SILVA et al., 2011). In evaluations of cultivars, genotype-environment interaction plays a key role and may greatly influence the selection process, though the logical difficulty is found in the selection of promising genotypes. In addition to detecting the genotypeenvironment interaction, it is important to estimate its magnitude over the manifestation of phenotypic traits.
The pronounced interaction evidences the need to evaluate the genotypes in varied environments in order to safely recommend the best among them. The component $c^{2}$ quantifies how much the component of the genotypesenvironment interaction explains phenotypic variance. This was verified by the greater influence of the interaction in the first group of hybrids for both of the considered variables (Table 2). The lowest influence was observed for SS content in the second group of hybrids.

The genotype-environment interaction occurs due to two factors: the first, called the simple part, owes to the magnitude of the variability differences between genotypes, and the second, called the complex part, depends on the genetic correlation of the genotypes in the environments (CRUZ and CASTOLDI, 1991). The average genotypic correlation of hybrid performance across different environments $\left(r_{\text {loc }}\right)$ provides the reliability of how constant the ordering of the hybrids is and, indirectly, furnishes the reability of the complex interaction. Corroborating the estimates of component $c^{2}$, it has been verified that the estimate of genetic correlation between environments $\left(r_{\text {loc }}\right)$ was high only for SS content in the second group of hybrids. This indicates that there was a predominance of the complex part of the interaction for the two traits evaluated, thereby making the selection process difficult. Previous studies in the Mossoró-Assu Agricultural Complex indicated the predominance of the complex interaction for productivity and SS content in Yellow melons (ARAGÃO et al., 2015; GUIMARÃES et al., 2016; NUNES et al., 2006; SILVA et al., 2011). Only Nunes et al. (2011b) found a predominance of the simple part of the interaction when measuring SS content in Galia melon hybrids evaluated across nine environments in the Mossoró-Assu Agricultural Complex.

Reducing the genotype-environmental interaction is possible by identifying those productive materials with greater stability and adaptability in the evaluated group. Resende $(2004,2007)$ developed the HMRPGVBLUP method, which includes studies of stability and adaptability, using genotypic data that incorporates stability, adaptability, and average desirable traits into a single statistic.

The Harmonic Mean of Genotypic Values (HMGV) allows for selection based on stability and productivity. According to this criterion, for productivity, the HC02 hybrid stood out in all three groups; and the HC-12 hybrid, in the third group (Table 3). For SS content, the most expressive hybrid were $\mathrm{HC}-01$ and $\mathrm{HC}-02$ in the first group, HC-02 and HC-09 in the second group, and HC-02 in the third group. The HMGV values are the exact same as the productivity or SS content values effected by instability, which certainly favors the selection of hybrids that are the most productive and of the best level of quality while at the same time being more stable. The HMGV effects instability when genotypes are evaluated across 
various environments, resulting in a new mean adjusted by this effect.

Producing melons requires the use of technology in aligment with modern irrigation techniques and an intense application of fertilizers and pesticides. In this context, melon breeders search for new cultivars of high adaptability. Adaptability refers to the ability of genotypes to be advantageously responsive to environmental improvements. To identify this trait, it is necessary to use appropriate methods along with existing techniques that measure the relative performance of the genotypic values (RPGV) that capitalizes on the ability of each lineage to respond to environmental improvements. For this criterion, the hybrids that stood out for each group, for the two evaluated traits, were rigorously the same as the ones described for the HMGV (Table 3).

The harmonic mean of the relative performance of genotypic values (HMRPGV), based on genotypic values predicted by way of mixed models, groups stability, adaptability and productivity, into a single statistic, thereby assisting in the selection of major genotypes (REZENDE, 2002). HMRPGV*MG provides the genotypic values of each genotype effected by instability and capitalized by adaptability. Considering all the environments employed in this study, based on the MHPRVG approach, the best hybrids for productivity were the hybrid HC- 02 of the first group, HC-02 and HC-09 of the second group, and HC02, HC-10, HC-11 and HC-12, of the third group (Table 4). For SS content, the major hybrids werw HC-01 and HC-02 in the first group, HC-02 and HC-09 in the second group, and HC-02, HC-10, HC-08, HC-13 and HC-14 in the third group (Table 4).

In order to earn profits, growers are in agreement that melon hybrids must yield at least $25.0 \mathrm{~kg} \mathrm{ha}^{-1}$. Therefore, the HC-02 hybrid stood out in the first group, hybrids HC-02, HC-09 and HC-10 in the second group, and all hybrids of the third group, with the exception of HC-13. All of the hybrids mentioned were more productive than the 'Hy Mark' hybrid. This hybrid was used as a control because it was the most grown Cantaloupe cultivar in the Mossoró-Assu Agricultural Complex in the last decade due to its productivity and excellent quality. In this work, the results results found for 'Hy Mark' are below those observed by the producers during the last few years.

Cantaloupes require at least $10 \% \mathrm{SS}$ content to be marketed in Europe. Therefore, this aspect must be highlighted about the hybrids of the first group. All the hybrids produced SS content of less than $10 \%$. The low HMRPGV value owes to the "rainy season" (March - May, 2010) when the hydrids were grown. This fact is evidenced when the 2010 and 2011 crop yields separetely (Table 5). The HMRPVG hybrids value in the "rainy season" (2010) were all lower than $7 \%$, which indicates very low quality. In contrast, in 2011, when the same materials were evaluated in the "dry" season, the predicted values were at least $9 \%$. The major hybrids, in a top-down order, were $\mathrm{HC}-02$ and $\mathrm{HC}-06$, at values greater than $12 \%$. These hybrids respond, on average, 1.17 and 1.13 times the average of the environment in which they are planted, respectively.

A great challenge for melon breeders is to cultivate melons durring the "rainy season", as observed in the contrasting performance of the hybrids of the first group during the years 2010 and 2011. In that season, the high precipitation $(>45 \mathrm{~m} \mathrm{~mm}$ ) was the main problem for the melon crop. In addition, the occurrence of diseases such as fruit blotches, caused by the bacterium Acidovorax avenae (ALVES et al., 2010), and mildew, caused by the fungus Pseudoperonospora cubensis (ALBUQUERQUE et al., 2015) are frequent. All these factors lead to low productivity and low SS content, thus reducing fruit quality. Said results were observed in this study (Table 5). To date, none of the hybrids have performed well durring this season in the primary producing sites in the Northeast region.

The hybrids HC-02, HC-09, HC-10 and HC-11 were considered the most promissing for cultivation in Mossoró-Assu Agricultural Complex during the dry season (July - December), having shown high HMRVGV values ( $>27 \mathrm{Mg}$ ha -1$)$ and high SS content $(>10 \%)$. These hybrids and the 'Hy Mark' control hybrid were evaluated in 2017 during the dry season (June - August) according to the farmer's choice of conditions in Mossoró and Baraúna, the main producing municipalities of the Mossoró-Assu Agricultural Complex, for productivity, fruit quality and shelf life (Table 6). Altogether, the hybrids stood out for the traits related to productivity and SS content in comparison to he control treatment performance.

However, hybrids HC-02, HC-11 and 'Hy Mark' stood out for pulp firmness and shelf life (internal and external fruit appearance). Regarding pulp firmness, the hybrids HC-02 and HC-11 and the 'Hy Mark' control presented higher estimates in relation to the HC-09 and $\mathrm{HC}-10$ hybrids. Those melons presented values of firmness within the requirements since Alves et al. (2000) reported the recommended firmness is $30 \mathrm{~N}$ in order to meet the market requirements.

The internal and external appearances are main characteristics in determining the shelf life of melons. Fruits that score 3.0 or lower are not recommended for marketig. In this work, hybrids HC-09 and HC-10 remained at an acceptable score of external appearence for up to 20 days post harvest, after which period the fruits show blemishes and sunken spots. Hybrids HC02 and HC-11 did not score less than 3.0 up to 30 days after harvest, indicating the fruits were still marketable. The cultivar 'Hy Mark' scored 3.0 at 28 days on shelves. Regarding the internal appearance, hybrids HC-09 and HC-10 showed scores lower than 3.0 after 19 days at the two evaluation sites. Fruits with scores lower than 3.0 
exhibited loose seeds and/or liquid in the inner cavity. Conversely, hybrids HC-02, HC-11 and 'Hy Mark' scored less than 3.0 until the moment of evaluated. (30 days on shelves).

The fruits produced in the Mossoró-Assu Agricultural Complexis exported on ships through the ports of Natal and Pecém in the state of Ceará. The melons exported through the Port of Natal are transported in refrigerated cargo holds, and those exported through the Port of Pecém are shipped in refrigerated containers. According to Morais et al. (2009), the time required for maritime transport and marketing in Europe is 28 days. Gonçalves et al. (1996) stated that a genotype has sufficient storage capacity for commercialization in the foreign market when its shelf life is at least 25 days. In fact, out of all the hybrids evaluated, only $\mathrm{HC}-02$ and HC-11, as well as the 'Hy Mark' control have a shelf life that allows for sales in Europe. However, it should be noted that hybrid HC-02 would be more suitable for the international market because of its low weight $(1.485 \mathrm{~g})$, while the heavier hybrid $\mathrm{HC}-11$ is better for the national market, (1.914.5 g).

Table 1- Hybrids, municipalities, year, temperature and rainfall data of evaluation environments.

\begin{tabular}{|c|c|c|c|c|c|}
\hline Group & Hybrids & Local & Year & Temperature ${ }^{1}\left({ }^{\circ} \mathrm{C}\right)$ & $\operatorname{Rainfall}^{2}(\mathrm{~mm})$ \\
\hline \multirow{6}{*}{1} & $\mathrm{HC}-01$ & Mossoró & 2010 & $\operatorname{Max}=32,5 \mathrm{Min}=22,5$ & 274 \\
\hline & $\mathrm{HC}-02$ & Baraúna & 2010 & $\operatorname{Max}=30,7 \mathrm{Min}=22,7$ & 194 \\
\hline & $\mathrm{HC}-03$ & Assu & 2010 & $\operatorname{Max}=31,4 \mathrm{Min}=22,6$ & 288 \\
\hline & $\mathrm{HC}-04$ & Mossoró & 2011 & $\operatorname{Max}=34,3 \mathrm{Min}=23,5$ & 0,0 \\
\hline & $\mathrm{HC}-05$ & Baraúna & 2011 & $\operatorname{Max}=33,3 \mathrm{Min}=21,8$ & 4,2 \\
\hline & HC-06 & Assu & 2011 & $\operatorname{Max}=32,8 \mathrm{Min}=23,2$ & 19,5 \\
\hline \multirow{4}{*}{2} & HC-02 & Mossoró & 2012 & $\operatorname{Max}=35,1 \mathrm{Min}=22,7$ & 0,0 \\
\hline & HC-07 & Baraúna & 2012 & $\operatorname{Max}=33,2 \mathrm{Min}=22,3$ & 0,0 \\
\hline & HC-08 & Assu & 2012 & $\operatorname{Max}=33,3$ Min $=22,1$ & 0,0 \\
\hline & HC-09 & Ipanguassu & 2012 & $\operatorname{Max}=32,9 \mathrm{Min}=21,9$ & 0,0 \\
\hline \multirow{9}{*}{3} & $\mathrm{HC}-10$ & Mossoró & 2013 & $\mathrm{Max}=34,1 \mathrm{Min}=23,2$ & 0,0 \\
\hline & HC-11 & Baraúna & 2013 & $\operatorname{Max}=33,6 \mathrm{Min}=22,4$ & 21,4 \\
\hline & $\mathrm{HC}-12$ & Assu & 2013 & $\operatorname{Max}=32,2 \mathrm{Min}=23,4$ & 10,0 \\
\hline & $\mathrm{HC}-13$ & Mossoró & 2014 & $\operatorname{Max}=34,5 \mathrm{Min}=22,7$ & 0,0 \\
\hline & HC-14 & Baraúna & 2014 & $\operatorname{Max}=33,1 \mathrm{Min}=22,5$ & 0,0 \\
\hline & $\mathrm{HC}-15$ & Assu & 2014 & $\mathrm{Max}=33,7 \mathrm{Min}=23,8$ & 1,7 \\
\hline & $\mathrm{HC}-16$ & Mossoró & 2015 & $\operatorname{Max}=34,3 \mathrm{Min}=23,1$ & 1,0 \\
\hline & & Baraúna & 2015 & $\operatorname{Max}=33,2 \mathrm{Min}=22,8$ & 0,0 \\
\hline & & Assu & 2015 & $\operatorname{Max}=32,8 \mathrm{Min}=22,1$ & 0,7 \\
\hline
\end{tabular}

${ }^{1}$ Mean of the maximum and minimum temperatures during the trial periods. ${ }^{2}$ Accumulated rainfall during the trials. 
Table 2. Deviance, components of variance, accuracy, heritability, genotypic and residual coefficients of variation obtained via individual REML, considering the joint analysis to yield and soluble solids content evaluated in Cantaloupe melon hybrids grown in the Mossoró-Assu Agricultural Complex across different environments.

\begin{tabular}{|c|c|c|c|c|c|c|}
\hline \multirow[t]{2}{*}{ Effect } & \multicolumn{2}{|c|}{$1^{\text {st }}$ Group } & \multicolumn{2}{|c|}{$2^{\text {nd }}$ Group } & \multicolumn{2}{|c|}{$3^{\text {rd }}$ Group } \\
\hline & Deviance & $\hat{\sigma}$ & Deviance & $\hat{\sigma}$ & Deviance & $\hat{\sigma}$ \\
\hline \multicolumn{7}{|c|}{ Yield $\left(\mathrm{Mg} \mathrm{ha}^{-1}\right)$} \\
\hline Complete model & 491,5 & & 315.4 & & 810.3 & \\
\hline Genotype & $\begin{array}{l}495,5 \\
\left(4,0^{*}\right)\end{array}$ & 0,3 & $\begin{array}{l}319.7 \\
\left(4,3^{*}\right)\end{array}$ & 6.5 & $\begin{array}{l}815,5 \\
\left(5,2^{*}\right)\end{array}$ & 2.9 \\
\hline $\mathrm{G} \times \mathrm{A}$ & $\begin{array}{c}504,0 \\
\left(12,5^{* *}\right)\end{array}$ & 10,7 & $\begin{array}{c}323.3 \\
\left(7,9^{* *}\right)\end{array}$ & 13.2 & $\begin{array}{l}819.3 \\
\left(9,0^{* *}\right)\end{array}$ & 3.1 \\
\hline Error & & 17,8 & & 24.1 & & 16.3 \\
\hline Phenotype & & 28,7 & & 43.8 & & 22.3 \\
\hline $\mathrm{h}^{2} \mathrm{mo}$ & & 0,1 & & 0.6 & & 0.8 \\
\hline$c^{2}$ & & 0,37 & & 0,30 & & 0,14 \\
\hline $\mathrm{Ac}_{\mathrm{g}}$ & & 0,3 & & 0.8 & & 0.9 \\
\hline $\mathrm{CV}_{\mathrm{g}}^{\mathrm{g}}$ & & 2,3 & & 9.5 & & 6.5 \\
\hline $\mathrm{CV}_{\mathrm{e}}^{\mathrm{g}}$ & & 17,5 & & 18.2 & & 15.2 \\
\hline$r_{\text {loc }}$ & & 0,03 & & 0,33 & & 0,49 \\
\hline Mean & & 24,1 & & 26.9 & & 26.4 \\
\hline \multicolumn{7}{|c|}{ Soluble solids content $(\%)$} \\
\hline Complete model & 251,6 & & 117,5 & & 328,9 & \\
\hline Genotype & $\begin{array}{l}252,1 \\
\left(0,5^{\text {ns }}\right)\end{array}$ & 0,2 & $\begin{array}{l}123,0 \\
\left(5,5^{*}\right)\end{array}$ & 0,6 & $\begin{array}{l}329,9 \\
\left(1,0^{\text {ns }}\right)\end{array}$ & 0,03 \\
\hline $\mathrm{G} \times \mathrm{A}$ & $\begin{array}{c}275,9 \\
\left(24,3^{* *}\right)\end{array}$ & 1,8 & $\begin{array}{c}118,3 \\
\left(0,8^{\text {ns }}\right)\end{array}$ & 0,1 & $\begin{array}{l}337,6 \\
\left(8,7^{* *}\right)\end{array}$ & 0,37 \\
\hline Error & & 1,7 & & 1,3 & & 1,24 \\
\hline Phenotype & & 3,6 & & 1,9 & & 1,64 \\
\hline $\mathrm{h}_{\mathrm{mg}}^{2}$ & & 0,3 & & 0,8 & & 0,3 \\
\hline$c^{2}$ & & 0,49 & & 0,08 & & 0,22 \\
\hline $\mathrm{Ac}_{\mathrm{g}}$ & & 0,6 & & 0,9 & & 0,5 \\
\hline $\mathrm{CV}_{\mathrm{g}}^{\mathrm{g}}$ & & 5,4 & & 7,5 & & 1,7 \\
\hline $\mathrm{CV}_{\mathrm{e}}^{\mathrm{g}}$ & & 15,7 & & 11,3 & & 11,1 \\
\hline $\mathrm{r}_{\mathrm{loc}}$ & & 0,10 & & 0,79 & & 0,07 \\
\hline Mean & & 8,2 & & 9,9 & & 10,0 \\
\hline
\end{tabular}

Deviance, LRT: Likelihood-ratio test (value between parenthesis); Var.: variance component. **,*: significative per chi-square test ( $<<0.01)$ and $(\mathrm{p}<0.05)$, respectively. $\hat{\sigma}$ : variance stimate; $\mathrm{h}_{\mathrm{mg}}^{2}$ : average heritability; $\mathrm{Ac}_{\mathrm{g}}$ : selective accuracy; $\mathrm{r}_{\text {loc }}$ : correlation between environments. 
Table 3. Stability of the genotypic values (HMGV) adaptability of genotypic values (RPGV) for yield and soluble solids content evaluated in Cantaloupe melon hybrids grown in the Mossoró-Assu Agricultural Complex across different environments.

\begin{tabular}{|c|c|c|c|c|c|c|}
\hline \multirow[t]{2}{*}{ Hybrids } & \multicolumn{3}{|c|}{ Yield $\left(\mathrm{Mg} \mathrm{ha}^{-1}\right)$} & \multicolumn{3}{|c|}{ Soluble Solids Content (\%) } \\
\hline & HMGV & RPGV & $\mathrm{RPGV}^{*} \mathrm{G}$ & HMGV & RPGV & $\mathrm{RPGV}^{*} \mathrm{G}$ \\
\hline \multicolumn{7}{|c|}{$1^{\text {st }}$ Group } \\
\hline HC-01 & 22,65 & 0,97 & 23,29 & 8,05 & 1,08 & 8,85 \\
\hline $\mathrm{HC}-02$ & 25,11 & 1,08 & 25,96 & 7,86 & 1,08 & 8,90 \\
\hline HC-03 & 24,50 & 1,04 & 24,94 & 7,36 & 0,98 & 8,07 \\
\hline HC-04 & 23,28 & 0,99 & 23,79 & 6,82 & 0,91 & 7,50 \\
\hline $\mathrm{HC}-05$ & 23,28 & 1,00 & 24,09 & 6,85 & 0,93 & 7,63 \\
\hline HC-06 & 23,61 & 1,00 & 24,07 & 7,54 & 1,05 & 8,64 \\
\hline 'Hy Mark' & 21,79 & 0,93 & 22,28 & 7,21 & 0,97 & 7,97 \\
\hline \multicolumn{7}{|c|}{$2^{\text {nd }}$ Group } \\
\hline HC-02 & 31,37 & 1,17 & 31,53 & 10,72 & 1,09 & 10,73 \\
\hline HC-07 & 23,60 & 0,88 & 23,85 & 9,56 & 0,97 & 9,56 \\
\hline HC-08 & 27,58 & 1,03 & 27,70 & 9,46 & 0,96 & 9,48 \\
\hline HC-09 & 25,80 & 0,99 & 26,80 & 10,51 & 1,07 & 10,52 \\
\hline 'Hy Mark' & 24,88 & 0,93 & 25,12 & 9,06 & 0,92 & 9,06 \\
\hline \multicolumn{7}{|c|}{$3^{\text {rd }}$ Group } \\
\hline HC-02 & 27,70 & 1,05 & 27,80 & 10,27 & 1,03 & 10,31 \\
\hline HC-08 & 27,03 & 1,03 & 27,22 & 10,09 & 1,01 & 10,13 \\
\hline HC-10 & 26,09 & 0,99 & 26,22 & 10,17 & 1,02 & 10,21 \\
\hline HC-11 & 27,12 & 1,03 & 27,28 & 9,73 & 0,97 & 9,76 \\
\hline HC-12 & 27,30 & 1,04 & 27,39 & 9,64 & 0,97 & 9,72 \\
\hline $\mathrm{HC}-13$ & 22,41 & 0,85 & 22,57 & 10,09 & 1,01 & 10,13 \\
\hline HC-14 & 25,85 & 0,99 & 26,02 & 10,07 & 1,01 & 10,10 \\
\hline 'Hy Mark' & 26,65 & 1,01 & 26,79 & 9,83 & 0,99 & 9,90 \\
\hline
\end{tabular}

Table 4. Stability and adaptability of genotypic values (HMRPGV) for yield and soluble solids content evaluated in Cantaloupe melon hybrids grown in the Mossoró-Assu Agricultural Complex across different environments.

\begin{tabular}{|c|c|c|c|c|}
\hline \multirow[t]{2}{*}{ Hybrids } & \multicolumn{2}{|c|}{ Yield $\left(\mathrm{Mg} \mathrm{ha}^{-1}\right)$} & \multicolumn{2}{|c|}{ Soluble Solids $\left({ }^{\circ}\right.$ Brix $)$} \\
\hline & HMRPGV & HMRPGV *GV & HMRPGV & HMRPGV *GV \\
\hline \multicolumn{5}{|c|}{$1^{\text {st }}$ Group } \\
\hline HC-01 & 0,95 & 22,97 & 1,07 & 8,83 \\
\hline HC-02 & 1,07 & 25,66 & 1,07 & 8,77 \\
\hline HC-03 & 1,03 & 24,73 & 0,95 & 7,85 \\
\hline HC-04 & 0,98 & 23,60 & 0,91 & 7,48 \\
\hline HC-05 & 0,99 & 23,87 & 0,92 & 7,57 \\
\hline HC-06 & 1,00 & 23,96 & 1,03 & 8,48 \\
\hline 'Hy Mark' & 0,92 & 22,19 & 0,96 & 7,90 \\
\hline \multicolumn{5}{|c|}{$2^{\text {nd }}$ Group } \\
\hline HC-02 & 1,16 & 31,44 & 1,09 & 10,73 \\
\hline HC-07 & 0,88 & 23,71 & 0,97 & 9,56 \\
\hline HC-08 & 0,97 & 26,15 & 0,96 & 9,47 \\
\hline HC-09 & 1,02 & 27,66 & 1,07 & 10,52 \\
\hline 'Hy Mark' & 0,92 & 24,92 & 0,92 & 9,06 \\
\hline \multicolumn{5}{|c|}{$3^{\text {rd }}$ Group } \\
\hline HC-02 & 1,06 & 27,78 & 1,05 & 10,52 \\
\hline HC-08 & 0,99 & 26,20 & 1,02 & 10,20 \\
\hline HC-09 & 1,03 & 27,24 & 1,03 & 10,30 \\
\hline $\mathrm{HC}-10$ & 1,04 & 27,38 & 0,97 & 9,69 \\
\hline HC-11 & 1,03 & 27,15 & 0,97 & 9,75 \\
\hline HC-12 & 0,85 & 22,51 & 1,01 & 10,12 \\
\hline HC-13 & 0,98 & 25,98 & 1,01 & 10,09 \\
\hline 'Hy Mark' & 1,01 & 26,77 & 0,98 & 9,87 \\
\hline
\end{tabular}


Table 5. Stability and adaptability of the genotypic values (HMRPGV) for yield and soluble solid content evaluated in Cantaloupe melon hybrids grown in the Mossoró-Assu Agricultural Complex in different environments (2010-2011).

\begin{tabular}{|c|c|c|c|c|}
\hline \multirow[t]{2}{*}{ Hybrids } & \multicolumn{2}{|c|}{2010} & \multicolumn{2}{|c|}{2011} \\
\hline & HMRPGV & HMRPGV *GV & HMRPGV & HMRPGV *GV \\
\hline \multicolumn{5}{|c|}{ Yield $\left(\mathrm{Mg} \mathrm{ha}^{-1}\right)$} \\
\hline HC-01 & 1,01 & 21,42 & 0,89 & 23,85 \\
\hline $\mathrm{HC}-02$ & 1,02 & 21,73 & 1,13 & 30,29 \\
\hline $\mathrm{HC}-03$ & 1,08 & 22,94 & 0,95 & 25,53 \\
\hline HC-04 & 0,98 & 20,86 & 0,98 & 26,44 \\
\hline HC-05 & 0,94 & 20,06 & 1,09 & 29,20 \\
\hline HC-06 & 1,01 & 21,42 & 0,98 & 26,31 \\
\hline 'Hy Mark' & 0,94 & 19,89 & 0,92 & 24,80 \\
\hline \multicolumn{5}{|c|}{ Soluble Solid Content (\%) } \\
\hline HC-01 & 1,03 & 5,98 & 1,07 & 11,38 \\
\hline HC-02 & 1,00 & 5,82 & 1,17 & 12,38 \\
\hline HC-03 & 1,04 & 6,03 & 0,83 & 8,78 \\
\hline HC-04 & 0,98 & 5,71 & 0,87 & 9,25 \\
\hline HC-05 & 0,97 & 5,63 & 0,94 & 10,00 \\
\hline HC-06 & 0,99 & 5,74 & 1,13 & 12,00 \\
\hline 'Hy Mark' & 1,00 & 5,82 & 0,91 & 9,72 \\
\hline
\end{tabular}

Table 6. Yield, number of comercial fruits per plant, average fruit weight, pulp thickness, pulp firmness, soluble solids content and shelf life of Cantaloupe melon hybrids obtained in commercial plots in the municipalities of Mossoró e Baraúna.

\begin{tabular}{lccccccc}
\hline Hybrids & \multicolumn{7}{c}{ Mean (Traits) } \\
\cline { 2 - 7 } & $\begin{array}{c}\text { YIE } \\
\left(\mathrm{Mg} \mathrm{ha}^{-1}\right)\end{array}$ & NCP & $\begin{array}{c}\text { AWF } \\
(\mathrm{g})\end{array}$ & $\begin{array}{c}\text { PT } \\
(\mathrm{cm})\end{array}$ & $\begin{array}{c}\text { PF } \\
(\mathrm{N})\end{array}$ & $\begin{array}{c}\text { SS } \\
(\%)\end{array}$ & $\begin{array}{c}\text { SL } \\
(\text { Days })\end{array}$ \\
\hline HC-02 & 36,23 & 3,51 & 1492 & 4,23 & 30,34 & 13,34 & 30 \\
HC-09 & 27,32 & 3,78 & 1324 & 4,15 & 27,76 & 13,12 & 19 \\
HC-10 & 30,87 & 3,23 & 1432 & 4,44 & 26,12 & 12,12 & 19 \\
HC-11 & 34,12 & 2,87 & 1854 & 4,23 & 30,11 & 11,34 & 30 \\
'Hy Mark' & 28,26 & 2,52 & 1432 & 4,31 & 31,12 & 12,12 & 30 \\
& & & & Baraúna & & & \\
HC-02 & 32,12 & 3,47 & 1478 & 4,39 & 30,93 & 12,90 & 30 \\
HC-09 & 31,12 & 3,23 & 1432 & 4,65 & 28,12 & 13,23 & 19 \\
HC-10 & 31,45 & 3,14 & 1453 & 3,98 & 21,12 & 13.30 & 19 \\
HC-11 & 33,23 & 2,98 & 1975 & 4,10 & 30,12 & 12,23 & 30 \\
'Hy Mark' & 26,23 & 2,55 & 1348 & 4,00 & 32,12 & 11,20 & 28 \\
\hline
\end{tabular}

YIE: yield, NCP: number of comercial fruits per plant, AWF: average fruit weight, PT: pulp thickness, PF: pulp firmness, SS: soluble solids content and SL: shelf life. 


\section{Conclusions}

Hybrids $\mathrm{HC}-02$ and $\mathrm{HC}-11$ are promising for cultivation in the environmental conditions of the Mossoró-Assu Agricultural Complex due to their high stability, adaptability, productivity and fruit quality.

Hybrids HC-02, HC-11 and 'Hy Mark' have a shelf life that allow them to be exported to foreign markets.

\section{References}

ALBUQUERQUE, L.B.; ANTONIO, R.P.; NUNES, G.H.S.; MEDEIROS, R.V.; SILVA FILHO, A.J.R. Caracterização morfológica de fontes de resistência de meloeiro a Pseudoperonospora cubensis. Revista Caatinga, Mossoró, v.28, p.100-107, 2015.

ALVES, A.O.; XAVIER, A.S.; VIANA, I.O.; MARIANO, R.L.R.; SILVEIRA, E.B. Colonization dynamics of Acidovorax citrulli in melon.Tropical Plant Pathology, Viçosa, MG, v.35, n.6, p.368-372, 2010.

ALVES, R.E.; PIMENTEL, C.R.; MAIA, .C.E.; CASTRO, E.B.; VIANA, F.M.; COSTA, F.V.; ANDRADE, G.G.; FILGUEIRAS, H.A.C.; ALMEIDA, J.H.S.; MENEZES, J.B.; COSTA, J.G.; PEREIRA, L.S.E. Manual de melão para exportação. Brasília: Embrapa, 2000.

ARAGÃO, F.A.S.; NUNES, G.H.S.; QUEIROZ, M.A. Genotype $\mathrm{x}$ environment interaction of melon families based on fruit quality traits. Crop Breeding Applied Biotechnology, Viçosa, MG, v.15, n.2, p.79-86, 2015.

CARBONELL, S.A.M.; CHIORATO, A.F.; RESENDE, M.D.V.; DIAS, L.A.S.; BERALDO, A.L.A.; PERINA, E.F. Estabilidade em cultivares e linhagens de feijoeiro e diferentes ambientes no Estado de São Paulo. Bragantia, Campinas, v.66, n.2, p.193-201, 2007.

CRUZ, C.D.; CASTOLDI, F.L. Decomposição da interação genótipos $\mathrm{x}$ ambientes em partes simples e complexa. Revista Ceres, Viçosa, MG, v.38, p.422-430, 1991.

FREITAS, J.G.; CRISÓSTOMO, J.R.; SILVA, F.P.; PITOMBEIRA, J.B.; TÁVORA, F.J.A.F. Interação entre genótipo e ambiente em híbridos de melão-amarelo no Nordeste do Brasil. Revista Ciência Agronômica, Fortaleza, v.38, n.2, p.176-181, 2007.
GOMES JUNIOR, J.; MENEZES, J.B.; NUNES, G.H.S.; COSTA, F.B.; SOUZA, P.A. Qualidade pós-colheita do melão tipo cantaloupe, colhido em dois estádios de maturação. Horticultura Brasileira, Brasília, v.19, n.3, p.223-227, 2001.

GONÇALVES, F.C.; MENEZES, J.B.; ALVES, R.E. Vida útil pós-colheita de melão 'Piel de Sapo' armazenado em condição ambiente. Horticultura Brasileira, Brasília, DF, v.14, p.49-52, 1996.

GUIMARÃES, I.P.; DOVALE, J.C.; ANTONIO, R.P.; ARAGÃO, F.A.S.; NUNES, G.H.S. Interference of genotype-by-environment interaction in the selection of inbred lines of yellow melon in an agricultural center in Mossoró-Assu, Brazil. Acta Scientiarum, Agronomy, Maringá, v.38, p.51-59, 2016.

GURGEL, F.L.; KRAUSE, W.; SCHMILDT, E.R.; SENA, L.C.N. Indicação de híbridos de melão para o Rio Grande do Norte. Revista Ceres, Viçosa, MG, v.52, n.299, p.115$123,2005$.

MELO, D.R.M.; GUIMARÃES, I.P.; COSTA FILHO, J.H.; NUNES, G.H.S.; SILVA, J.R.; ARAGÃO, F.A.S. Controle genético da herança sólidos solúveis em frutos de meloeiro. Journal of the Interamercan Society for Tropical Horticulture, v.54, p.146-150, 2011.

MORAIS, P.L.D.; SILVA, G.G.; MAIA, E.N.; MENEZES, J.B.Avaliação das tecnologias pós-colheita utilizadas e da qualidade de melões nobres produzidos para exportação. Ciência e Tecnologia de Alimentos, Campinas, v.29, p.214-218, 2009.

NUNES, G.H.S.; ANDRADE NETO, R.C.; COSTA FILHO, J.H.; MELO, S.B. Influência de variáveis ambientais sobre a interação genótipos $\mathrm{x}$ ambientes em meloeiro. Revista Brasileira de Fruticultura, Jaboticabal, v.33, p.1194-1199, 2011a.

NUNES, G.H.S.; MADEIROS, A.E.S.; GRANGEIRO, L.C.; SANTOS, G.M.; SALES JUNIOR, R. Estabilidade fenotípica de híbridos de melão amarelo avaliados no Pólo Agroindustrial Mossoró-Assu. Pesquisa Agropecuária Brasileira, Brasília, DF, v.41, n.9, p.57-67, 2006.

NUNES, G.H.S.; SANTOS JÚNIOR, H.; GRANGEIRO, L.C.; BEZERRA NETO, F.; DIAS, C.T.S.; DANTAS, M.S.M. Phenotypic stability of hybrids of Galia melon in Rio Grande do Norte state, Brazil. Anais da Academia Brasileira de Ciências, Rio de Janeiro, v.83, n.12, p.14211434, 2011b. 
NUNES, G.H.S.; SANTOS JÚNIOR, J.J.; ANDRADE, F.V.; BEZERRA NETO, F.; MENEZES, J.B.; PEREIRA, E.W.L. Desempenho de híbridos do grupo inodorus em Mossoró. Horticultura Brasileira, Brasília, DF, v.23, n.1, p.90-94, 2005.

PATTERSON, H.D.; THOMPSON, R. Recovery of inter-block information when block sizes are unequal. Biometrika, Cambridge, v.58, p.545-554, 1971.

PUPIN, S.; SANTOS, A.V.A.; ZARUMA, D.U.G.; MIRANDA, A.C.; SILVA, P.H.M.; MARINO, C.L.; SEBBENN, A.M.; MORAES, M.L.T. Produtividade, estabilidade e adaptabilidade em progênies de polinização aberta de Eucalyptus urophylla S.T. Blake. Scientia Forestalis, Piracicaba, v.43, n.105, p.127-134, 2015.

REGITANO NETO, A.; RAMOS JUNIOR, E.U.R.; GALLO, P.B.; FREITAS, J.G.; AZZINI, L.E. Comportamento de genótipos de arroz de terras altas no estado de São Paulo. Revista Ciência Agronômica, Fortaleza, v.44, n.3, p.512-519, 2013.

RESENDE, M.D.V. Genética biométrica e estatística no melhoramento de plantas perenes. Brasília: Embrapa, 2002. 975 p.

RESENDE, M.D.V. Métodos estatísticos ótimos na análise de experimentos de campo. Colombo: Embrapa Florestas, 2004. 57p.

RESENDE, M.D.V. Selegenreml/Blup: sistema estatístico e seleção genética computadorizada via modelos lineares mistos. Colombo: Embrapa Florestas, 2007. 359p.

RESENDE, M.D.V.; DUARTE, J.B. Precisão e controle de qualidade em experimentos de avaliação de cultivares. Pesquisa Agropecuária Tropical, Goiânia, v.37, n.3, p.182194, 2007.
SALES JUNIOR, R.; DANTAS, F.F.; SALVIANO, A.M.; NUNES, G.H.S. Qualidade do melão exportado pelo porto de Natal-RN. Ciência Rural, Santa Maria, v.36, n.1, p.286-289, 2006.

SANTOS, G.A.; RESENDE, M.D.V.; SILVA, L.D.; HIGA, A.; ASSIS, T.F. Interação genótipos x ambientes para produtividade de clones de Eucalyptus L'Hér.no Estado do Rio Grande do Sul. Revista Árvore, Viçosa, MG, v.39, n.1, p.81-91, 2015.

SILVA, G.O.; CARVALHO, A.D.F.; VIEIRA, J.D.; GIOVANI, B. Verificação da adaptabilidade e estabilidade de populações de cenoura pelos métodos AMMI, GGE biplot e REML/BLUP. Bragantia, Campinas, v.70, n.3, p.494-501, 2011.

SILVA, J.M.; NUNES, G.H.S.; COSTA, G.G.; ARAGÃO, F.A.S.; MAIA, L.K.R. Implicações da interação genótipos $\mathrm{x}$ ambientes sobre ganhos com a seleção em meloeiro. Ciência Rural, Santa Maria, v.41, n.1, p.51-56, 2011.

TORRES, F.E.; TEODORO, P.E.; SAGRILO, E.; CECCON, G.; CORREA, A.M. Interação genótipo x ambiente em genótipos de feijão-caupi semiprostrado via modelos mistos. Bragantia, Campinas v.74, n.3, p.255$260,2015$.

YAN W. GGE Biplot vs. AMMI graphs for genotype-byenvironment data analysis. Journal of the India Society of Agricultural Statistics, New Dehli, v.65, n.2, p.181193, 2011. 